\title{
Elizabeth I's Royal Progresses: A Study of Formal Orations and Poetic Recitations
}

\author{
Sihem Garrouri \\ Department of Languages and Translation \\ Faculty of Science and Arts, Rafha \\ Northern Border University, Arar Saudi Arabia \\ Email: sihem.garrouri@gmail.com
}

Received: 3/20/2021 Accepted: 7/23/2021 Published: 8/25/2021

\begin{abstract}
:
The present study examines the rhetoric of inconsistency in the representation of Queen Elizabeth I through a reading of formal orations and poetic recitations written during her royal progresses. These literary resources, which were deliberately designed to promote the Elizabethan monarchy, offer illuminating examples of Elizabeth's struggle to cultivate a distinctive royal identity. I would suggest that the tactical rhetorical practice of creating paradoxical images was an essential constituent of Elizabeth's statecraft to cement her authority and reinforce her legitimacy. Indeed, the deployment of a discourse of contradiction that shaped Elizabeth's progresses was a necessary and practical approach to overcome the vulnerability of an unmarried female monarch. The analysis of contradictory imagery is a valuable contribution to comprehend the complexity of Elisabeth's representation and her strategies of exercising power in a patriarchal society. The research shows that Elizabeth employed the medium of creating ambiguous images as a rhetorical tactic to overcome gender bias against the female monarchy, and her courtiers utilized the same approach to advance their own agendas. It explores two ambiguous representations: masculine/ feminine portrayal and virgin/ maternal depiction.
\end{abstract}

Keywords: contradictory representations, Elizabeth I, formal orations, poetic recitations, royal progresses

Cite as: Garrouri, S. (2021). Elizabeth I's Royal Progresses: A Study of Formal Orations and Poetic Recitations. Arab World English Journal for Translation \& Literary Studies 5 (3) 2-16. DOI: http://dx.doi.org/10.24093/awejtls/vol5no3.1 


\section{Introduction}

Elizabeth I's regal progresses were the public forums in which her royal power was most fully exhibited. The 23 royal visits between 1559 and 1602 illustrate their essentiality, allowing Elizabeth to enhance her popularity and bolster her regal authority. Elizabeth tactfully impressed her people as a successful leader. Her travels to different cities played an essential role in creating a public image that represented her as both king and Queen, male and female, and virgin and mother (Cole, 1999).

Apart from their entertaining aspect, progresses nevertheless contribute to political significance, crafting an image of a mighty sovereign. These theatrical settings also reveal Elizabeth's perpetual attempt to construct her public persona and persuade her subjects of her abilities and distinguished nature. Accurate discursive examples of formal orations and poetic recitations show that the Queen and her subjects created paradoxical images. Such display of conflicting images was essential for a childless, female ruler to overcome misogynist views. This approach acknowledges that she needed these two forms of verbal representation to consolidate her power, whereas her courtiers deployed them to build up goodwill and credibility for themselves.

As Montrose (2006) suggested, Elizabeth's cult was not "a unified and coherent system but rather was hybrid and improvisatory- therefore unstable and contradictory" (p. 104). Strong (1999) also postulated that the progresses reveal a clear image of Elizabethan sovereignty as "complex and full of paradoxes and contradictions" (p. 116). Building on Montrose and Strong's terms, this research aims at scrutinizing two textual materials: orations and poetry to gain some insight into what Strong called "calculated ambiguity" (Strong, p. 116) or the practice of this fractured tactical representation, proving that verbal imagery was crucial to maintain loyalty. These significant literary resources support my argument: orations and poems delivered during Elizabeth's progresses contain several details about the construction of erratic images designed to overcome the negative stereotypical attitudes towards female sovereignty and cultivate an image of a mighty Queen. Put simply, these written accounts are a significant source of information about Elizabeth's representation and empowerment, demonstrating how the application of literary means reflects the political management of a female sovereign.

\section{Literature Review}

The three volumes of Nichols (1823), a collection of documents, are the principal primary source of the progresses. While some scholars focused on one particular progress as Dovey (1996), who provided a detailed study about the Queen's journey to East Anglia., others have examined the themes of Elizabeth's progresses, notably Archer, Goldring, and Knight (2007). Scholars such as Cole (2007) foregrounded the significance of Elizabeth's progresses as an occasion to negotiate power and advance interests. Anglo (1997) focused on the exchange of messages during the progresses. Moreover, Wardell (2011) postulates that the progresses were a "ceremonial dialogue" or an "interactive discourse" between the Queen and the people, allowing her to promote her image. Santini (2011) provided examples of speeches and pageants involving romance imagery to negotiate power between the Queen and her courtiers and celebrate her glory. Strong (1999), Montrose (2006), and Frye (1996) have also studied the royal visits as ceremonial occasions, using 
primary material such as pageants, speeches, parades, masks, and dramatic performances. They find in them proof of a dialogue between Elizabeth and her people. Strong shows that pageants, miniatures, and portraits allowed her to communicate with her subjects and shape their perception. Recent studies highlighted the issue of gender and power. Frye (1996), for instance, suggested that the sovereign and her courtiers compete to control her image, and Levin (2013) posited that the Queen reshaped views on gender to defend her sovereignty. No scholar has yet juxtaposed orations and verse and commented on the significance of their rhetorical tactics.

\section{Methods}

In its methodology, therefore, this essay purposely juxtaposes orations with poetry to compare the images displayed by Elizabeth and her subjects. Such juxtaposition underwrites the discrepancy in Elizabeth's representation and the startling intricacy of image-making. By juxtaposing Elizabeth and her courtiers' words, we grasp the representation of a vulnerable female monarch struggling for legitimacy. This essay is in alignment with new historicism, scrutinizing marginal historical material. The choice of material is based on the conflicting images examined in this project, rather than being chronological or author-based. Space does not permit the discussion of every aspect of paradoxical imagery; therefore, the focus will be on two illustrative conflicting representations: masculinity versus femininity and virginity versus maternity. The analysis of these two sites of ambiguity permits us to contextualize Elizabeth's approach to leadership and prove that she participated in creating such images.

\section{Analysis}

\section{Masculine Gifts versus Feminine Traits}

Elizabeth and her courtiers carefully cultivated her public persona during her royal visits, casting various contradictory images that enabled them to face foreign and domestic challenges and reassure people of her ability to overcome them. Indeed, her gender raised questions about her capability to rule the kingdom effectively. As women were deprived of undertaking the role of leadership in early modern England, there was an urgent need to regularly justify and fashion a mode of female sovereignty that was highly textual. Such situation of subordination gave way to opposing representations. Indeed, Elizabeth managed to assert her right to rule in a maledominated society, in part, through her public image. She was aware of the importance of creating an image, and therefore, in her travels, she cleverly employed her eloquence to achieve political ends. She should have recognized that language had the power to enhance her royal identity and realized that "monarchs created themselves and the images that language created in its audience" (Frye, 1996, p. 4). Her people were also aware of the significance of eloquence. In her progress at Warwick, 1572, the recorder indicated that he was aware that this occasion necessitated "fine speech, the highest was required" (Nichols, 1823a, p. 312) to celebrate her virtues.

Hence, being alienated in a masculine world, Elizabeth's strategy to exercise power was to appropriate feminine and masculine traits, as demonstrated in the political theory of the King's Two Bodies. She developed a unique style of leadership that combines masculine and feminine attributes, "a sort of male mind within a female body" (Wagner-Wright, 2012, p. 1). Gender bias, political vulnerability, and the legitimacy of female rule were essential motives for selfrepresentation. In her struggle for identity in a highly patriarchal society, Elizabeth placed great 
emphasis on displaying images as propaganda devices that allowed her to transcend the limitations imposed by the culture of her times, and she employed her gender for "self-branding, even selfaggrandizement" (Evans, 2014, p.15). The Queen reconfigured gender expectations by distinguishing between the "body natural", the physical body, and the "body politic", the institution of monarchy. Accordingly, Elizabeth was projected in a "newly gendered fashion" (Levin, 2013, p.122), using the medieval doctrine of the King's Two Bodies. Kantorowicz (1997) posited that this theory "form one unit indivisible, each being fully contained in the other" (p. 3). Put simply, Elizabeth "occupied a borderland between male and female, and by creating a third neutral gender, neither fully male nor fully female, it allowed her to create an identity considered suitable for ruling a nation" (Moylan, 2009, p.14). Hackett (1995) defined the body politic as "the timeless and essence of monarchy" and the body natural as "the private, human, mortal body of the temporary incumbent" (p. 21). Hence, the Queen possessed a natural mortal body which might indicate infirmities such as illness and death and an eternal body politic that is transferred to an heir when the ruler passes away.

In her first speech, on $20^{\text {th }}$ November 1558, at Hatfield Palace, she stated that as a woman, her natural body was weak, but once crowned, she gained a powerful body politic. Moreover, she declared: "And as I am but one body naturally considered, though by His permission a body politic to govern" (Leah S. Marcus, Janel Muller, \& Mary Beth Rose, 2000, p. 52). As evident in this speech, she proclaimed that she had acquired her masculine attributes by divine interference. In this way, this concept intensified the theory of the Divine Rights of Kings, as a fundamental principle of Calvinist political thought, which enabled her to justify her sovereignty since she was placed in her seat of governance by God. Consequently, to govern well was a sacred responsibility. She projected herself as a divinely inspired caretaker of her people and promised to be fair and wise. The theory of the King's Two Bodies reinforced the idea of the sacredness of the monarch and elevation above humankind. This concept was an efficient tool to enter the political life and avoid male resentment by preserving her womanly duties, yet, at the same time, performing her monarchical roles. It was a valuable political device in defining and defending female monarchy.

Her language demonstrates her attempt to create an identity or a political persona by shaping her public image. Yet, she did not attempt to hide her femaleness as she crafted male supremacy (Schweizer, 2008). Hackett (1995) argued that Elizabeth emphasized "stereotypical masculine virtues" such as eloquence, decisiveness, and justice without being viewed as "unnaturally mannish or Amazonian" (p. 1). She used this medieval theory to justify what Frye (1996) called "engendering herself", i.e., performing male and female roles or both according to the political circumstance (p.13). It is worth noting that Elizabeth is portrayed as both male and female or prince and princess. In Norwich, 1578, a child welcomed her as the "most gracious Prince, undoubted Soverraigne Queene" (Nichols, 1823b, p. 144), and in a speech, she was addressed: "O mighty prince" (p. 165). Another illustration is the oration of Stephan Limbert, a public-school master: "moste excellente Princesse" and "most learned Lady and Princesse" (p. 171). One final example is the speech of Tryton at Kenilworth Castle in 1575, calling her "most mightie Prince", "peerless Prince", "puissant Prince", and "Queene" (Nichols, 1823a, p. 500). 
Her subjects also employed the theory of the Queen's two bodies in her representation. James Aske proudly declared, "Although she (is) by Nature weake,/ Because her sex no otherwise can be:/ Yet wants she not the courage of her Sire" (Nichols, 1823b, p. 338). He asserted that she is frail by nature, but she inherited bravery from her father, Henry VIII. An alternative image appeared to overcome frailty: Elizabeth as a figure of perfect femininity possessing masculine qualities. In 1565, at Coventry, Mr. John Throgmorton, recorder of Coventry, called attention to the Queen's two bodies:

as the natural body cannot long continue safely, except the head, as principal part thereof, do enjoy perfect health, so much the more in the politic body, all the parts thereof wax weak, and sooner decay, except the head, and chief governor of them does live and continue in most healthful and prosperous estate. (Nichols, 1823a, p.193)

Furthermore, he asserted that she ruled by "God's Divine Providence" (p.194), addressed her as both "Prince" and "Queen", cited her "manifold virtues" such as mercy, wisdom, knowledge, and justice, and humbly referred to people's loyalty and commitment which is manifested in putting their lives at her command. Since people appreciate divine providence and virtues, Elizabeth seems to employ them for her political purposes. In Machiavelli's (1998) (1532) words, the ruler should seem "merciful, faithful, humane, trustworthy, religious" (p. 59) and "show himself a lover of virtue" (p. 91).

An illustrative example of Elizabeth's appropriation of masculine qualities, which involves an unnatural implication, is the 1588 speech at Tilbury. Encouraging her troops to face the Spanish invasion by King Philip II, Elizabeth referred to her masculine attributes: "I may have the body of a weak and feeble woman, but I have the heart and stomach of a king" (Marcus et al., 2000, p. 326). Here, she highlighted her regal strength and courage to compensate for the perceived deficiencies of her gender. The battlefield was exclusively a masculine field. To overcome her precarious situation as an unmarried female ruler, she represented herself as both male and female, king and Queen. She asserted that she had the qualities of a King of England, such as courage. It is an incredible infusion in which masculine characteristics are fused in a female body. Montrose (2006) suggested that her "strategy of self- empowerment involves a delicate balance of contrary tactics" (p. 149). She surpassed the vulnerability of her female body by appropriating masculine virtues as knightly courage vested in her body politic. Most strikingly, however, the English body politic is identified with the female body of the monarch. In other words, the purity and integrity of the Queen's body mirror the country's state. By claiming virginity, Elizabeth preserved her nation from internal turmoil and external invasion. Accordingly, the invasion of the English territory is metaphorically equivalent to the violation of her virginal female body. Thus, symbolically preserving Elizabeth's virginity is equal to protecting the kingdom from potential invasion (Montrose, 2006).

Nevertheless, this comparison underlines the monarch's role in establishing peace, her elevation, and self-sacrifice. Indeed, she was in the battlefield "to live and die amongst (them) all; to lay down for (her) God, and for (her) kingdom, and (her) people, (her) honor and (her) blood, even in the dust" (Marcus et al., 2000, p. 169). The rhetorical significance of these lines lies in the 
"strategic equivocation between masculine and feminine modalities of honor and of bloodletting, between military heroism and virgin- or sacrificed virginity" (Montrose, 2006, p. 151). Additionally, Elizabeth highlighted her commitment to her realm by cautiously choosing her words and presenting herself a loving monarch who would spare her blood and her honor for her people: "I myself will venter my royal blood; I myself will be your general, judge, and rewarder of every one of your virtues in the field" (Marcus et al., 2000, p. 326). The reference to spending her bloodshed is a masculine characteristic of the Renaissance context. She was always balancing three arguments, emphasizing her legislative, military, and royal powers. To foreground her abilities, she uses repetitive phrasing "I myself", anaphora. Here, she was not referring to her regal qualities, rather her personal skills. She called attention to masculine traits such as bloodshed and courage and feminine qualities as love and honor. Courage is a male quality, whereas peacefulness, mercifulness, and love are feminine attributes. Leadership in war transforms Elizabeth into a goddess and a superhuman figure. In early modern England, women were considered inferior to men. Therefore, a warrior Queen became an ideal, exceptional woman.

Surprisingly, however, Elizabeth is ostensibly praised as a Queen of peace at home and also abroad. She was reluctant to engage in wars and protected the nation against tyrants and invaders. This is obvious in her visit at Norwich in 1578: "best a Prince of Peace" (Nichols, 1823b, p. 161) and at Kenilworth in 1575: "But peace shall governe all daies/ encreasing subjects love/ You shall be called the Prince of Peace/ and peace shall be your shield" (Nichols, 1823a, pp. 486487). In these two lines, the repetition of the term "peace" reinforces the idea that she imposed stability in her nation. Thus, the generous compliment of the Queen, using antitheses, casts Elizabeth as a distinguished ruler. This is paradoxical: A Queen, who is a peace-maker, yet, she is a warrior monarch. Because of her wisdom, her subjects lived in such peace and tranquility. Therefore, they had to "performe all the dutie of faith and love" (Nichols, 1823b, p. 172). Above all, people concede: "we will love youre Highnesse with all our heartes, minds, and endouvoures" (p.173). These intriguing lines show how fervently her subjects professed their loyalty and devotion and illustrate that love, peace, and obedience are intrinsically connected. In this sense, orations and poems played a crucial role in political practice. Textual evidence demonstrates that the royal visits were a highly essential political adjunct for a female ruler to maintain obedience and loyalty. They were occasions not only to display the Queen's virtues, stage her power by engaging in a "mutually instructive dialogue", but also disseminate her regal propaganda (Keenan, 2007, p. 102-103).

Several poems and orations highlight her feminine virtues of mercy and peacefulness: During the progress at Norwich in 1578, Limbert announced his lack of eloquence to accurately describe her "notable mercie" (Nichols, 1823b, p. 157); The Mayor also addressed her: "O most merciful Prince". He pointed out that she is "full of a certain wonderful love" (p.167). Besides, the Mayor of Windsor, in 1586, honored her as a "merciful" sovereign, reminded conspirators that she is a legitimate monarch, and claimed that she is a "tender sexe" and "gratious Soveraigne" with "Princely excellencies", thus blending female and male attributes. He amplifies her image by stating that she is "above all praise" (pp. 472- 473). At Kenilworth Castle, Deepedesire, expressing his grief for her departure, claimed that she is incomparable: "O Queen without compare" (Nichols, 1823a, p. 521). 
The qualities of mercy and tenderness were also underlined in her passage through the city of London, where she received "tender obedience and love" (1823a, p.58). At St. Dunstones Church, a child offered her an oration, and the Queen responded: "I here see thys mercyfull worke towarde the poore, whom I muste in the middest of my royaltie nedes remembre!" (p.55). She showed her sympathy with the poor, declared she would not forget them, and promised to be a worthy Queen. Tenderness and love are essential feminine qualities that Elizabeth and her subjects emphasized in the royal visits to achieve political gains. In this respect, Shenk (2010) noted that Elizabeth utilized the discourse of love to enfold "the nation and its church into an image centered on her person" (p. 18).

Accordingly, progresses were strategic events for both parties to show love, commitment, and sacrifice. For instance, during her Coronation, on Sunday 15th January 1559, Elizabeth said to the Lord Mayor, Sir Thomas Leigh, and the people of London: "persuade yourselves that for the safety and quietness of you all I will not spare if need be to spend my blood" (Marcus et al., 2000, p. 5). Using her rhetorical abilities, she cultivated the image of a self- sacrificing and loving monarch to gain political ends. Indeed, the theme of love is intrinsically linked to obedience, as evident in these lines penned by Thomas Churchyard during Elizabeth's entertainment at Suffolk and Norfolk in 1578: "a prince raigneth, and with what obedience and love good subjects do receive hir (...) all the sheers of England are most willing to do their duties to the utmost of their powers" (Nichols, 1823b, p. 180). The use of overstatement: "all" and the superlative "most" underline the subjects' willingness to do their responsibilities. It seems that love was a means of achieving obeisance. The display of love provided the ground for the construction of female authority precisely because it was a real force in maintaining obedience, thus, an advantage for the Queen. Courtiers highlighted her "sincere affection, and unfayned goodwill, which (they) bare to (her) Highnesse, most excellent princesse" (p.171). More interestingly, they admit admiring her more than themselves: "yea, to love hir Grace much better than our own lives (....) to dye for hir sake". This connection between love and obedience is also demonstrated in the Mayor's last oration delivered in Norwich: "shew of our love and obedience" (p.168).

It seems that verse and orations were designed to stratify the courtiers' dedication to Elizabeth, particularly as a loving Queen. In her public procession through London, 1558, the Queen rejoiced at the "so earnest love of subjectes" (Nichols, 1823a, p. 38). It was a uniquely significant occasion to "shew her most gracious love toward the people" (p. 39). The city of London was a stage wherein "the noble-hearted Princess (...) her most loving People" did act. A child delivered his welcoming oration and expressed the subjects' respect and fondness of the Queen. Her people were gifted by "blessing tongues" (p. 39) to praise and hail her and "true hertes" to love and "skip for joy" (p. 40). The child's reference to the heart and the tongue touched the heart of the Queen: "So that she with rejoysyng visage did evidently declare that the wordes tooke no lesse place in her minde, than they were moste heartely pronounced by the chylde, as from all the heartes of her moste heartie Citizeins" (p. 40). She reinforced her love using polyptoton: the term heart is used as a noun, adverb, and adjective. This idea of faithful, genuine hearts and tongues is also mentioned in another poetic verse delivered by a child: "Thy loving subjectes will with true hearts and tonges praie" (p. 54). Additionally, in his greeting oration, in the 1578 progress in Norwich, the Lord Mayor assured the Queen of collective and extravagant loyalty, obedience, and 
goodwill: "The most loving, obedient, and well willing subjects to perform, for the preservation of your crown, and advancement of your highness" (Marcus et al., 2000, p. 175). Elizabeth also assured him that she is a loving monarch.

These demonstrations of reciprocal love are also evident in Worcester, 1975, Mr. Bell delivered an oration in which he thanked her for her "careful breaste, moche tenderyng the virtuous education of youth in the feare of God, and with pryncelie pittie" (Nichols, 1823a, p. 546). Tenderness, love, and pity are feminine qualities that her subjects admiringly celebrate:

This faithfull love to us your subjects (most excellente Queene) lightly layde up in our heartes, and scarcely covered as it were in the ground, but deeply rooted, so that by no stormes nor tempests of fortune it can be shaken, by no engines overthrown, by no force or violence overtaken. (Nichols, 1823b, p. 172)

The speaker personified love since it can be faithful. He projected the image of a loving Queen, claiming that true love is everlasting and conquers all. The repetition of the quantifier "no", reveals that her love is deeply rooted and is never shaken by the most severe storms or defeated by the most powerful engines or violent forces. Another manifestation of love is at Kenilworth in 1575. When Elizabeth was hunting, Master Gascoigne addressed her:

Your Majesty being so highly esteemed, so entirely beloved, and so largely endued by the Celestial Powers; you can yet continually give eare to the councel of these terrestrial companions, (...) What pleasures have been for you prepared, what great goodwill declared, what joy and comfort conceived in your presence, and what sorrowe and greef sustained by likelihoode of your absence. (Nichols, 1823a, p. 515)

He glorifies her image as an admired and highly esteemed sovereign, using the adverb of frequency "so". Antonyms such as presence/absence, joy/ sorrow, celestial/ terrestrial, and happy/ grief underline the contradictory feelings that her presence and absence caused. Thus, "Elizabeth is the Queen of love" (Shenk, p. 129). Another such example of reciprocal admiration and opulent flattery is the welcome speech of a boy in the city of Bristow, 1574: "A welcome friend, that all men loves, and noen alive doth haet" (Nichols, 1823a, p. 396). The assertion that "all" people love her and no one hates her is hyperbole that emphasizes their admiration. She had enemies such as Catholics, the Pope, Philip II of Spain, and the Queen of Scots. The boy acknowledged that people could "spend their goods, their lands, and lives, her staet in peace to save" (p. 398). In this sense, both Elizabeth and her subjects claimed self- sacrifice.

The deployment of a discourse of ambiguity that shaped Elizabeth's imagery in her progresses is also conspicuous in representing her as a virgin and mother.

\section{Maternal Delineation versus Virgin Appropriation}

One notable feminine depiction promoted by Elizabeth and her courtiers is to project her as the mother of the kingdom of England. Asserting metaphorical motherhood is a particularly strategic way employed by a female ruler as a substitute to physical motherhood and an 
instrumental device to assure legitimacy (Broad \& Green, 2009). Although marriage was a solution to the problem of succession and the struggle with her advisors who urged her to marry, she was reluctant to experience motherhood. The acute concern was about who would rule after her. Above all, the Queen's principal duty is to produce a legitimate heir to the throne to maintain stability and avoid civil strife. Possibly, Elizabeth rejected the many suitors who courted her because she refused to be a mere spouse and share her powers with a consort. Besides, her father, Henry VIII, executed her mother, Anne Boleyn, and her stepmother, Catherine Howard. In addition, her halfsister, Mary I, unwisely married a foreign king, Philip of Spain, and put the stability of her kingdom at risk. Possibly, Elizabeth feared marriage because childbirth was risky in early modern England. She must have learned that celibacy is not as dangerous as marriage. Consequently, virginity and metaphorical motherhood were valuable means to avoid such threats. Furthermore, giving hope to suitors was a "trick" to maintain the alliance with powerful nations (Santamarta \& Luz, 2006, p. 147).

From the outset of her reign, Elizabeth exploited maternal imagery. In 1559, she declared to her parliament: "I have already joined myself in marriage to an husband, namely, the kingdom of England" (qtd. in. Wilson, 1987, p. 525). Her symbolic marriage to England was a valuable device to present the mother image. She also told her parliament, in 1563, "I assure you all, that though, after my death you may have many stepdames, yet shall you never have any a more natural mother than I mean to be unto you all" (Marcus et al., p. 72). In this sense, she exploited the mother and child relationship as a political asset. She, moreover, declared: "I am already married to the realm of England when I was crowned with this ring (...) I am sworn when I was married to the realm not to alter the laws of it" (p. 65). Accordingly, Elizabeth altered the well-established traditional metaphor that monarchs are married to their nations. The monarch symbolizes the husband who occupied a high position, and the kingdom stands for the wife who was inferior. However, Elizabeth considered herself a loyal wife in the service of her nation (Broad \& Green, 2009 , p. 103). She adopted motherly and wifely imagery as an entirely effective apparatus for monarchical authority to highlight feminine traits such as love, sacrifice, and affection. The metaphor of maternity which became prevalent in cultivating Elizabeth's image entails contradictory implications of affection and tenderness and punishment and domination. Similarly, crafting an image of female perfection with supernatural powers implies that women are irrational, indecisive, and unpredictable.

Progresses provide ample examples of maternal delineation. Welcoming Elizabeth in Norwich, 1578, the orator addressed her: "my Princesse and my peerlesse Queene, my loving nurse and mother" (Nichols, 1823b, p. 146). Upon her departure, the speaker told her: "Farewell, oh Queene, farewell, oh Mother dere" (p.165). She was also portrayed as the defender of true faith and mother of all commonwealth people: "Thou Nurse of Religion, Mother of the Commonwealth, Beautie of Princes". Furthermore, Limbert, in Norwich, proclaimed that: "Nature hath not engendered in any man such large love, and so great goodwill (....) obey and reverence your majestie, being the Mother and Nurse of this whole commonwealth" (p. 171). One notable feature in the preceding quotation is the uniquely tight linkage between motherhood, obedience, and love. Maternity was a powerful tool that could turn her gender, which disqualified her from leadership, into an asset by conclusively moving away from the belief in male supremacy and the centrality 
of marriage for a female ruler. Additionally, obedience as a political end was maintained by love and respect for a tender, affectionate mother.

Of particular importance is the oration in her progress at Coventry in 1565: "like as you are a mother to your kingdom, and to the subjects of the same, by justice and motherly care and clemency, so you may, by God's goodness and justice, be a natural mother" (Nichols, 1823a, p. 197). Mr. John Throgmorton addressed Elizabeth as a mother of her kingdom and her subjects, foregrounding her maternal traits such as care and kindness and encouraging her to experience natural maternity. He sought to transform metaphorical motherhood into physical maternity and advised her to settle the succession issue by producing an heir to the throne of England. However, Elizabeth decided to remain single, a clever tactic to display the virgin image. Elizabeth wanted the image of the Virgin Queen to prevail. In 1559, she addressed her parliament: "and in the end this shall be for me sufficient: that a marble stone declare that a Queen, having reigned such a time, lived and died a virgin" (Marcus et al., 2000, p. 58). In the late 1570s, once it became increasingly clear that the Queen was past child-bearing, Elizabeth and her counselors recognized the need to present the virgin image. Needless to mention that the strategic appropriation of virginity was a traditional religious symbol that allowed her to sustain her authority.

In the cult of the virgin image, she utilized numerous spiritual and worldly emblems. For instance, she identified herself with figures in the Old Testament, such as Deborah and Judith, and figures in the New Testament, as the Virgin Mary. The cult of the Virgin Queen reveals the continuous need to accommodate new ideas by making use of material already in hands. Elizabeth became a "substitute for the Virgin Mary, filling a post-reformation gap in the psyche of the masses, who craved a symbolic virgin mother figure" (Hackett, 1995, p. 7). Yates (1977) suggested that the images of the Virgin Mary were taken from Churches and monasteries; however, "another bejeweled and painted image was set up at court, and went in progress through the land for her worshippers to adore" (p. 79). Her appropriation of sacred Christian symbolism, the Virgin Queen image, was created to bolster her political power and inspire her subjects (Doran, 2003). This representation would lead to reverence and enhance her religious duties. Hence, religion and politics are strongly interconnected: "both are modes of imposing social structures and systems of representation upon hierarchies of power" (Hackett, 1995, p. 18). Elizabeth recognized the importance of exhibiting symbolic images to maintain her royal power and the significance of the representational device as a compelling approach to solidify her rule. Accordingly, the exercise of authority and imagery became intertwined.

There is sustainable evidence that shows the celebration of the virgin image during Elizabeth's visits, showing that she was placed in her respective throne as a divine instrument. We can observe such figuration during her visit to the University of Cambridge. In 1564, William Master delivered an oration highlighting the Queen's virginity. She responded: "God's blessing of thyne heart" (Nichols, 1823a, p. 161). Thus, she encouraged such depiction. At Norwich's entertainment, she was represented as an incomparable Virgin Queen: "Whoever found on earth a constant friend, / That may compare with this my Virgin Queen?" (Nichols, 1823b, p. 163). Her purity is also appreciatively celebrated "Let not a Queene, a Virgine pure, which is, and ever was" (p. 174).

Arab World English Journal for Translation \& Literary Studies 
As Montrose (2006) has put it, Marian symbolism is a means of empowerment of Elizabeth, although a risky approach (p. 80) since it was viewed as a threat to the established Anglican Church. Indeed, Mary's virginity is a Catholic Dogma that the reformers rejected. This debate caused strife between the two branches of Christianity: Catholicism and Protestantism. In England, it was a reminder of the Old Faith, which was prohibited. A possible reason for the cultivation of the Virgin image is to provide Catholics with a virtuous Protestant figure they could admire, especially because chastity was highly valued in that era. It was a strategic policy of reconciliation of both religious denominations. The Female monarch's appropriation of symbols associated with the Virgin Mary could have been used to signify the sacredness of the Queen and probably to convince Catholics that she did not wholly depart from the Old Faith.

She was, moreover, depicted as exquisitely beautiful yet unobtainable. Orators and poets emphasize her elevation above women, as well as her purity and divinity. The juxtaposition of virginity and divinity paved the way to cast her as a goddess. The 1578 progress over East Anglia formed a "vast social drama (...); its ground plot was the triumph of the Virgin Queen over false idols and popish conspiracies" (Montrose, 2006, p. 89). Elizabeth's subjects identify her with Queene Juno, the Queen of Heaven, Goddess of women, and marriage; Minerva Lady, Goddess of wisdom, arts, and craft; and Venus, Goddess of love, beauty, and marriage. They claimed that she possessed all the qualities of them: "These sundry giftes of goddesses three Elizabeth possesseths:/ By Providence hir people's peace and comfort she increaseth" (Nichols, 1823b, p. 175). Thus, the poet referred to the maternal figuration by comparing her with Juno, the Mother Goddess. Intriguingly, the allusion to Elizabeth as Juno reveals that the systematic attempt to replace the Queen of England with the Queen of heaven transforms her into an idol (Montrose, 2006). The reference to the three classical Goddesses is meant to emphasize Elizabeth's virtues, divinity, and achievements which match their accomplishments. This comparison projects an exceptional female leader who, thanks to her learning excellence, brought peace and comfort to her kingdom.

Mythological, classical, and Catholic representations generate multiple identities or "multiform" images": a mother of her subjects, a providential Virgin Queen, a chaste goddess of love and beauty. These discrepant, fractured images might be said to constitute more an effective tactic of expedience than one either of criticism or contempt, a practical strategy for both parties. She excels all mythical figures by uniting their unique traits and virtues. In this way, she was depicted as an unprecedented figure, emphasizing her absolute perfection and divinity.

A further reference to classical elements which refers to Elizabeth as a virgin Queen and enhances diversity and discrepancy is quite evident in a song sung in Norwich:

Dame Juno thought the highest place most meete

For hir, bicause of riches was hir throne.

Dame Venus thought, by reason of hir love,

That she might claime the highest place above.

The Virgins state Diana still did prayse,

And Ceres praysed the fruit of fertile soyle:

And Prudence did Dame Pallas chiefly raise:

Minerva all for eloquence did strive. (Nichols, 1823b, pp. 149-150) 
Elizabeth is presented as "The Queene of Virgins only she" (1823c, p. 63) and alluded to as Astraea, the virgin goddess of justice and chastity who established a Golden Age. At Theobalds, 1593-94, Sir Robert Cecil penned the Hermits oration and offered her "a candle of Virgin's wax, meete for Virgin Queene" (p. 243).

Nonetheless, the imagery of virginity and motherhood is confusing. Indeed, maternal imagery is employed to justify virginity. Additionally, the virgin/mother depiction is a cultural construction. It was a cultural projection that distinguishes between male and female voices. Arguably, the patriarchal society assigned to Elizabeth contradictory meanings.

\section{Discussion}

There is strong evidence that Elizabeth's royal progresses were an instrumental approach to foster her female sovereignty. They were unique opportunities to establish direct contact with her subjects and cast an image of a powerful, extraordinary female ruler. Her royal visits were also a useful outlet to display the magnificence of the ruler, show "the multi-layered, competing voices of the people who participated in Elizabethan Progresses" (Cole, 2007, p. 27), and illustrate the fact that multiple, fragmentary images are significant features of Elizabeth's representation. Progresses, thus, provide valuable evidence of the discrepancy of Elizabeth's representation. They were also occasions to express her tenderness and love towards her subjects and enhance her popularity.

By projecting the male/ female and virgin/ mother representations, Elizabeth and her courtiers forwarded their asymmetric goals: hers to transcend gender boundaries and cast herself as a superior, inspiring female ruler and exert "a strong psychological hold upon her subjects" (Levin, 2013, p. 87); theirs to define their own identity and advance their interests. In other words, the Queen affirmed her central role as a monarch, whereas her subjects gained favor and power, conferred their concerns, and presented their anxieties. Accordingly, both the Queen and her subjects utilized the progresses to discuss political opinions.

It is also evident that orations and poems contain a wealth of information about creating contradictory depictions. Nevertheless, inconsistent imagery needs further scrutiny using other verbal and visual documents such as plays, pageants, government correspondence, and portraits, illuminating new ways to comprehend Elizabeth's image and political practice. Additionally, other conflicting depictions should be investigated, notably divinity/ humanity, to get a close insight into Elizabeth's representation. E. K. Chambers (1923) is an essential primary source to scrutinize this phenomenon of discrepancy.

\section{Conclusion}

This essay reveals that the mixing of dichotomies: masculine/ feminine and virgin/mother is a tactic applied by Elizabeth and her advisors to transgress the marginalization of women. In a male-dominated society, creating new imagery was necessary to accommodate a single, childless female sovereign. To address the problem of gender, courtiers attempted to reconcile male kingship with the unmarried female body. Accordingly, Elizabeth and her advisors boldly and selfconsciously produced a distinctive style of regal adoration, resulting in multiple contradictory 
representations. This strategy of creating conflicting imagery shows the vulnerability of the female monarchy and calls into question her authority.

As this investigation has shown, formal orations and poetic recitations provide rich material to examine the cult of Elizabeth in her progresses. These literary texts are contextually significant in understanding her strategies of exercising authority, the complexity of her representation, and the motivations for self-representation. Elizabeth's progresses represent a public stage of monarchical public representation. They were never spontaneous occasions; instead, they were carefully crafted to construct her image. In other words, progresses were strategically arranged to display the power of the Queen, emphasize her specialness, and reinforce her elevated status and exceptional qualities. These planned platforms allowed her to express her affection and love to her people and declare motherhood and self-sacrifice, a wise tactic to win their support.

Furthermore, the primary sources considered in this essay demonstrate that two sites of contradiction- male/ female and virgin/ mother- are crucial elements in understanding the representation of Elizabeth in her progresses. These sources indicate the strong connections between Elizabeth's approach to self-representation and the subjects' portrayal of their monarch. The examination of formal orations and poetic recitations delivered during her royal visits, as calculated public performances, also illustrates the dynamics of ambiguity and the complexity of fashioning Elizabeth's image. Elizabeth and her people played a crucial role in projecting a fractured, multi-layered persona for mutual benefit. Consequently, her representation is inextricably complex since it includes elements of ambiguity.

\section{About the Author}

Dr. Sihem Garrouri is an Assistant Professor of English at Northern Border University, Saudi Arabia. She studied at the University of Caen Normandy, France. Her research interests include Renaissance studies, the Elizabethan era, and history of thoughts and politics. Garrouri's recent publications include: "Queen Elizabeth I: The Rhetoric of a Unique Paradoxical Image" and "Mythologizing the Memory of Gloriana". ORCID ID: https://orcid.org/0000-0001-6600-4870

\section{References}

Anglo, S. (1997), Spectacle, Pageantry, and Early Tudor Policy, Oxford: Clarendon Press.

Archer, J. E., Goldring, E. E, \& Knight, S. S. (2007). The Progresses, Pageants, and Entertainments of Queen Elizabeth I, Oxford: Oxford University Press.

Broad, J. \& Green K. (2009). A history of Women's Political Thought in Europe 1400- 1700, Cambridge: Cambridge University Press.

Chambers, E. K. (1923). The Elizabethan Stage, Oxford: Clarendon Press.

Cole, M. H. (2007). Monarchy in Motion: An Overview of Elizabethan Progresses. In J. E. Archer, E. Goldring, \& S. Knight (eds). The Progresses, Pageants, and Entertainments of Queen Elizabeth I (pp. 27-45). Oxford: Oxford University Press.

Cole, M. H. (1999). The Portable Queen: Elizabeth I and the Politics of Ceremony, Amherst: University of Massachusetts Press.

Doran, S. (2003). Virginity, Divinity and Power: The Portraits of Elizabeth I. In S. Doran \& T. S. Freeman (eds). The Myth of Elizabeth I (pp. 171- 199), New York: Palgrave Macmillan. 
Dovey, Z. (1996). An Elizabethan Progress: The Queen's Journey into East Anglia, 1578, Fairleigh Madison: Dickinson University Press.

Evans, C. (2014). The Heart of a King: Gender Components Affecting the Leadership and Political Rhetoric of Elizabeth I. In I. M. Lockhart \& K. M. Lanham, (eds.). Global Women Leaders: Studies in Feminist Political Rhetoric (pp. 3- 18). Lanham: Lexington Books.

Frye, S. (1996). Elizabeth I: The Competition for Representation, New York and Oxford: Oxford University Press.

Hackett, H. (1995). Virgin Mother, Maiden Queen: Elizabeth I and the Cult of the Virgin Mary, Basingstoke: Macmillan Press LTD.

Kantorowicz, E. (1997). The King's Two Bodies: A Study in Mediaeval Political Theology (1957), Princeton: Princeton University Press.

Keenan, S. (2007). Spectacular and Spectacle: Royal Entertainments at the Universities in the 1560s, In J. E. Archer, E. Goldring, \& S. Knight, (eds.) The Progresses, Pageants, and Entertainments of Queen Elizabeth I (pp. 86- 103). Oxford: Oxford University Press.

Levin, C. (2013). The Heart and Stomach of a King: Elizabeth I and the Politics of Sex and Power (1994), Philadelphia, University of Pennsylvania Press.

Machiavelli, N. (1998). The Prince (1532). (2 ${ }^{\text {nd }}$ ed., H. C. Mansfield, trans.). Chicago and London: The University of Chicago Press.

Marcus, L. S., Mueller J., \& Rose M. B. (2000). Elizabeth I: Collected Works. London: The University of Chicago.

Montrose, L. (2006). The Subject of Elizabeth, Authority, Gender, and Representation, Chicago: The University of Chicago Press.

Moylan, T. P. (2009). Playing the Crown: Civic and Great House Pageantry in the Reign of Elizabeth I, (Unpublished Ph.D. dissertation). Saint Louis University, USA.

Nichols, J. (1823). The Progresses and Public Processions of Queen Elizabeth, vol.1, London: Nichols.

Nichols, J. (1823). The Progresses and Public Processions of Queen Elizabeth, vol.2, London: Nichols.

Nichols, J. (1823). The Progresses and Public Processions of Queen Elizabeth, vol.3, London: Nichols.

Santamarta L. \& Luz M. (2006). Gloriana's Rule: A Spanish Ambassador's Viewpoint. In R. C. Homen, \& F. Vieira, (eds.), Gloriana's Rule: Literature, Religion and Power in the Age of Elizabeth (pp. 141- 150). Porto: Porto Editorial.

Santini M. (2011). Romance Imagery in Elizabethan Entertainments and Tournaments. In A. Petrina (ed). Queen and Country: The Relation between the Monarch and the People in the Development of the English Nation (pp. 37- 58). Berne: Peter Lang AG.

Schweizer, F. (2008). Queen Elizabeth I and Shakespeare: Images of Gender, Power, and Sexuality. (Unpublished Ph.D. Dissertation). University of Rhode Island.

Shenk, L. (2010). Learned Queen: The Image of Elizabeth in Politics and Poetry, New York: Palgrave Macmillan.

Strong, R. (1999). The Cult of Elizabeth: Elizabethan Portraiture and Pageantry (1977), London: Pimlico. 
Wagner-Wright, S. (2012). Common Denominators in Successful Female Statecraft: The Political Legacies of Queen Elizabeth I, Indira Gandhi, and Margaret Thatcher, A Journal of the Oxford Round Table, (1), 1- 16.

Wardell, F. (2011), Queen Elizabeth I's Progress to Bristol in 1574: An examination of Expenses, Early Theatre: A Journal Associated with the Records of Early English Drama, Vol. 14. (1).

Wilson, K. M. (1987). Women Writers of the Renaissance and the Reformation, Athens and London: The University of Georgia Press.

Yates, F. (1977). Astraea: The Imperial Theme in the Sixteenth Century, Harmondsworth: Penguin Books. 